[Holmes, T. (1995). The Centre for Early Childhood Studies/Te Pumanawa Rangahau Kohungahunga. New Zealand Annual Review of Education, 4, 25-38]

\section{The Centre for Early Childhood Studies/Te Pumanawa Rangahau Kohungahunga}

\section{TONY HOLMES}

\section{Abstract:}

The Centre for Early Childhood Studies/Te Pumanawa Rangahau Kohungahunga is a new initiative to develop and promote early childhood education in Aotearoa/New Zealand. The Centre aims to initiate, co-ordinate, facilitate and supervise early childhood research, organise seminars and conferences, collect and disseminate information, analyse and critique early childhood policy, and work on behalf of early childhood educators. The Centre's work will complement other early childhood initiatives, and will invite collaboration with early childhood groups, centres and educators. The Centre will become a resource available to all those committed to working for quality early childhood education and enhanced professional recognition.

Tn 1992 the Wellington College of Education and the Education Department of Victoria University entered into a partnership to create a new Faculty of Education in order to deliver degree level teacher education programmes. Early childhood education (ECE) was identified as one of several special areas of focus and a proposal for the establishment of a Centre for Early Childhood Studies was approved by the Faculty Board in 1993. During 1994 the Centre was provided with office, library and study space within the Victoria University Education Department and initial development work was begun. Formal approval by the Councils of the University and the College of Education was anticipated early in 1995 . The Centre plans to bring together early childhood lecturers and post-graduate students from the university and the college, and early childhood teachers, researchers and other early childhood specialists to work collaboratively on a range of projects to enhance the professional development and recognition of early childhood education in Aotearoa/New Zealand.

This report places the Centre in the context of early childhood education in Aotearoa/New Zealand today, and discusses some possible developments. It is based on the author's discussions with colleagues at the college and the university, representatives of early childhood sector organisations and other early childhood specialists, and investigations into the scope and viability of a number of Centre functions in the United States while on a Vocational Development award under the Fulbright programme (Holmes, 1994).

\section{The Centre and Early Childhood Education in Aotearoa/New Zealand}

\section{Recent developments in early childhood education}

In Aotearoa/New Zealand the early childhood education (ECE) sector has developed in an ad hoc manner establishing a diverse range of services in response to community needs. There have been three main types of centre-based service over most of the last 50 years (out of more than 25 services overall):

- Playcentre, a parent co-operative movement, which has trained its own supervisors in-service since its establishment in the 1940s;

- Kindergarten, the only substantially state-funded service before the 1989 reforms, with teachers pre-service trained in teachers' colleges/colleges of education; and

- the wide diversity of childcare services (full-day, part-day, community and private, for-profit and not-for-profit) with no formal training programmes until the 1970s.

In the early 1980s Te Kohanga Reo (Maori language nests), the exponentially growing indigenous early childhood movement, were established, and Pacific Island peoples' language nests developed from the late 1980s. Both have their own teacher education programmes. Other services, for example, Montessori, Steiner, have their own educational philosophies, knowledge bases, pedagogies, staff training/teacher education programmes and standards of quality.

Early childhood worker/teacher unions (Kindergarten Teachers' Association (KTA), Early Childhood Workers' Union (ECWU), and the Combined Early Childhood Union of Aotearoa (CECUA)) provided vision and leadership for the early childhood field from the 1970s 
through into the 1990s. Their collaborations and amalgamations (ECWU with KTA, and CECUA with the New Zealand Educational Institute (NZEI) in 1993) have provided direction for other developments.

In 1986, the Government abolished the longstanding administrative division of "care" from "education" by transferring the responsibility for childcare from the Department of Social Welfare to the (state) Department of Education, which was responsible for the other main early childhood services.

In 1988 the one-year Childcare Certificate Training and the two-year Kindergarten Diploma training were redeveloped as a three-year Diploma of Teaching (ECE), equivalent in status to the three-year Diploma for primary teachers. This benchmark qualification provides the core knowledge, skills, understandings and values for the beginning teacher, and, subsequently teacher registration at the end of a period of supervised practice.

Between 1989 and the present time there have been major structural reforms in the administration of education (Meade, 1988; Department of Education, 1989), and in curriculum and assessment (Ministry of Education, 1993). There has been a trend towards the privatisation of education. An education market has been created which has increased inequalities in access to, the funding of, and the outcomes from, educational services. In the early childhood field the gains realised at the end of the 1980s have been progressively lost in the 1990s (i.e., the staged plan for equitable early childhood service funding, progress towards the parity of status and compensation of workers and teachers, accountability measures and programme quality, and equity of access) by policy reversals, funding cuts and the re-emergence of an ideology of motherhood (Hayden, 1991) which legitimates the withdrawal of state support and leaves the responsibility for young children with individual parents/whanau. (This has been well argued and documented by Cooper and Royal-Tangaere, 1994; Kell Easting, 1992; May, 1991, 1992; Meade, 1991; Nuttall, 1991).

Hayden has suggested that an unresolved conflict between an ideology of gender equality and a deeply entrenched ideology of motherhood has affected early childhood policy developments in a number of advanced capitalist economies. These two conflicting ideologies engage where ECE policy is constructed.
The first NZ early childhood draft curriculum guidelines, Te Whariki: Draft Guidelines for Developmentally Appropriate Programmes in Early Childhood Services (Ministry of Education, 1993), were developed by multidisciplinary teams inclusive of Maori and Pacific Island representation. Te Whariki provides guidelines for the creation of culturally and developmentally appropriate curricula for all early childhood programmes in Aotearoa/New Zealand.

\section{The place of the Centre in early childhood education}

The Centre is expected to develop a number of specific functions. This work will complement that of other early childhood specialists working for the advancement of early childhood education. The functions currently being considered include the following:

- to organise and contribute to seminars, conferences and other forums on issues of relevance to the early childhood field;

- to establish an archive on the her/history of early childhood education, a library to hold specialist early childhood books and journals, and NZ early childhood research;

- to build an electronic data base, and an early childhood education index which may in the future contribute to a NZ education index;

- to produce a regular publication, initially in the form of a newsletter, and later as a journal;

- to develop a research programme in collaboration with other organisations, and experienced early childhood teachers in the field;

- to publish the research undertaken in the Centre as occasional papers or monographs;

- to provide a facility for visiting early childhood specialists and a resident research fellow;

- to provide policy analysis and critique; and

- to raise awareness of the issues facing ECE and advocate for children and their families. 


\section{Three Major Areas of Focus for Centre Activity}

Research in early childhood and early childhood teacher education

The focus on research is to enhance the historically small body of local research in this field, and to exploit the enormous potential both for replication of overseas work and for original research. In Aotearoa/ New Zealand we have relied for too long on overseas research to inform early childhood teacher education and early childhood centre practice. This has become evident during the recent development of the early childhood components of the BEd courses (Cooper and Royal-Tangaere, 1994). The scope of NZ research needs to be expanded in order to address adequately and appropriately our research agendas. In the past early childhood research in this country has consisted of small projects limited by available funding which reflected the low status and priority attached to this work. Only recently has this situation changed, with a number of larger scale projects underway (for example, Smith et al., 1994; Meade et al., 1994).

Research is one of the ways to enhance programme quality for children and to enhance the professionalisation of the field (Goodnow, 1989; Almy and Biber in Spodek et al., 1988). Currently the majority of early childhood teachers do not consider research to be part of their professional role. A certain reluctance on their part to regard themselves as having a role as researchers with a responsibility and capacity for enquiry has helped to maintain their perception that they need to be concerned only with practice. Most have relied on other early childhood specialists to produce new knowledge which has then been applied in early childhood settings. The new early child hood curriculum guidelines, Te Whariki (Ministry of Education, 1993) have been designed to encourage the development of reflective practice. The teacher-asresearcher approach is also developed in the early childhood Diploma and BEd courses. Over the next few years it is expected these will transform current perceptions and practice and provide a new model for early childhood teachers in the field.

The Centre for Early Childhood Studies aims to bring together early childhood lecturers and post-graduate students from the university and the college, and early childhood teachers, researchers and other early childhood specialists to work collaboratively on a range of projects. The development of a research culture in the field, and the involvement of early childhood teachers as research associates is a key part of this work. A clearinghouse to support this work, as exists in the US (ERIC) and has been proposed in Australia (Rodd, 1990), is described in the next section.

\section{Information services}

In Aotearoa/New Zealand there is no equivalent to the US ERIC system comprising 16 subject specific clearinghouses and multiple services, and accessible through CD-ROM, on-line, by telephone (no charge within the US) and fax. ERIC alone is estimated to have 100,000 documents directly related to early childhood issues (Katz, 1993). Australia has Austrom, a CD-ROM based education index. In this country there is only a motley collection of user-unfriendly databases. For more than 20 years there has been no commitment to providing an essential information service. Pickens $(1990,1993)$ details this sad history and states:

The most obvious characteristic of the NZ social science and education information systems, in short, is their lack of system, and the result has been a kind of information poverty (Pickens, 1990:102).

If early childhood research is to flourish a comprehensive electronic education index is essential. Nowhere is the need felt more than in the information-starved field of early childhood education. Information in such an index could be shared with the rest of the world as our contribution to the global body of information we continue to access and use. Unlike governments in some other countries (ERIC and Austrom are federally funded systems) ours has not supported or funded the development of a national education index. Recent efforts to bring library and other interested parties together for a feasibility study have failed. It appears that information in this country will continue to be accessed through fragmented sources such as Index NZ (INNZ), NZ Bibliographic Network (NZBN), NZ National Bibliography (NZNB), Educ Pacific, and a number of other local indexes.

In Aotearoa/New Zealand the Centre has a number of options for access to information. For research, CD-ROM services can be provided with an up-front fee for unlimited use of this disk-based service. On-line services usually have a time-on-line charge as well as a user fee. At the Centre, on-line services could be provided through the university computing facility. Direct on-campus, and dial-in access is possible. For early childhood teachers in centres, on-line services could be provided by a number of topic-specific bulletin boards, and/or the establishment of an early childhood clearinghouse sited at the university.

Currently the Learning Link service of NZ On-line (Telecom Education Foundation based on a similar US system) provides access to a host computer at Taranaki Polytechnic and the global Internet system. It is operating in NZ schools and provides a low cost access suited to school and early childhood centre users. To date no early childhood 
material is available on the Learning Link. Although few early childhood centres currently have the equipment to access these systems it is expected that access will increase rapidly. Many have equipment at home and most of the local and regional early childhood organisations have, or will soon have, the required equipment. Hindin (1994), a leading developer of a user-friendly interface to NZ On-line, estimates that:

current statistics point to exponential growth of up to 15 percent per month in use of the Internet for world-wide data exchange.

The Centre plans to bring together the fragmented and scattered information resources on ECE in this country and to establish a clearinghouse to support its research programme. This central resource could include a library, an archive to collect and preserve unique and significant NZ materials for research work, a comprehensive data base, a journal and research publications.

\section{Professional leadership, advocacy and recognition}

The concept of professionalism for ECE is complex. Discussions have been widespread (Ade, 1982; Katz, 1984; Spodek, Saracho and Peters, 1988; Stonehouse, 1988; Silin, 1985; Radomski, 1986). Staged career pathways based on levels of accomplishment have been proposed. In a field as diverse as ECE, it is necessary to develop a new concept of professionalism (Dresden and Kimes Myers, 1989) which is inclusive of the wide diversity of ECE. Models of professionalism borrowed from other established professions often use a single path approach, and a single definition which are often exclusive in their application. These are unsuitable for early childhood education, which requires a dynamic model of professionalism because there is no one standard of entry to the profession due to the diversity and varied levels of qualifications and experience of people who work with young children (Bredekamp and Willer, 1992; Smith et al., 1994).

Feeney (1987) has developed criteria for the profession which include a commitment to professional development along with many of the more usual criteria such as a specialised knowledge base, conformity to a code of ethics, standards of practice and quality regulation, and autonomy and self-regulation. The US National Association for the Education of Young Children (NAEYC) has proposed a model based on a career "lattice" (Bredekamp, 1992; Johnson and McCracken, 1994; Bredekamp and Willer, 1992). This "new paradigm" of professionalism (Willer and Bredekamp, 1993:63) is constructed from a multi-dimensional continuum of professionalising or "lattice", which includes those beginning training through to highly qualified and experienced teachers. It demands a commitment to ongoing professional development, opportunities for that development, and the supervision of that development.

In ECE there are no clearly defined pathways and standards for professional development, or the creation of a career structure, or a just structure for compensation (salaries and conditions). In a survey of 100 childcare centres in NZ in 1993, Smith has found that compensation is linked to status, i.e., that those who earn more, feel better about their work, value their work more and feel more professional (Smith et al., 1994).

There are pros and cons in the development of professionalism. Parents' perceptions of teachers may be negatively affected and they may feel excluded and alienated from the close relationships many of them have shared with their children's teachers. However the benefits are substantial, and the "new paradigm" attempts to include parents and offer advantages to all in delivering quality (Bredekamp and Willer, 1993).

Attitudinal barriers to progress in the development of professionalism (USMECPD, 1991) come both from inside and outside the profession. From outside there is an ignorance and lack of recognition of the hard and dedicated work of early childhood teachers. From the inside many early childhood teachers still hold onto a practitioner consciousness focused on the established and traditional roles of working with young children. Few practitioners are comfortable with the managerial and supervisory aspects of early childhood programmes. This situation can often be the result of the premature promotion of teachers to leadership positions before they are developmentally ready and able to provide leadership (Rodd, 1992: 17). An additional barrier to progress is that the majority of teachers are not comfortable with articulating their educational philosophy and pedagogical approaches or communication with outside professional organisations, or with political action.

The Centre aims to draw together the elements of the profession, establish criteria for the profession in Aotearoa/New Zealand, propose directions for the development of the profession, and communicate the vision and the reality of early childhood work to the public, politicians and other professional organisations. This promotion of the profession is essential if early childhood education is to receive the recognition it deserves. To date the major work in this country has been the 
development of a code of ethics by a national working group (Dalli and Cherrington, 1994) which parallels work in Australia (Stonehouse and Creaser, 1991; Australian Early Childhood Association (AECA), 1991) and in the US by the National Association for the Education of Young Children (Feeney and Kipnis, 1992).

Although significant progress had been made over the last decade, ECE remains marginalised, undervalued, underappreciated and largely invisible to those not directly involved in it (Smith, 1990). This is understandable in a world in which there is international agreement about the value to society of quality ECE, but little real commitment by way of adequate resourcing. Politics affect children's lives. Children themselves have no access to the political process and are dependent on others to articulate their needs and to get their needs met. Children need strong and effective advocates. Early childhood teachers and other specialists have a professional responsibility to advocate for a fairer deal for young children (Goffin, 1991). The Centre aims to provide policy analysis and research data to support early childhood advocacy.

\section{Conclusion}

The establishment of the Centre for Early Childhood Studies will provide opportunities for professional leadership in early child hood education in Aotearoa/New Zealand. The Centre aims to bring early childhood education in from the margins of the education system and place it centre stage where it is visible, can be valued for its contribution, and receive proper recognition. The early childhood field in Aotearoa/ New Zealand has a clear vision, established and proven teacher education and teacher development programmes, a substantial knowledge base, and a developing code of ethics. However, it still faces attitudinal, economic, qualification and regulatory barriers. The Centre aims to raise the profile and status of early childhood education in Aotearoa/New Zealand through developments in collaborative research, in providing information, library, and clearinghouse services, in preserving and sharing our her/history, in publications, through seminars and conferences, in establishing a resident research fellowship, in professional leadership and advocacy, and in enhancing the professional activity of early childhood teachers. This report has outlined a number of possible functions for the new Centre. What is actually achieved will depend on the level of resourcing of the Centre and the contributions from those active across the field of early childhood education.

\section{Acknowledgement}

The author wishes to acknowledge early childhood colleagues at the Wellington College of Education and the Victoria University Education Department and representatives of early childhood sector organisations for their contributions towards the development of the Centre and the reviewing of the material presented in this paper.

\section{References}

Ade, W. "Professionalisation and its Implications for the Field of Early Childhood Education", in Young Children, March 1982.

Bredekamp, S. "Composing a Profession", in Young Children, January 1992.

Bredekamp, S. and Willer, B. "Of Ladders and Lattices, Cores and Cones: Conceptualising an Early Childhood Professional Development System", in Young Children, March 1992.

Bredekamp, S. and Willer, B. "Professionalising the Field of Early Childhood Education: Pros and Cons", in Young Children, March 1993.

Clyde, M. and Rodd, J. "Ethical Dilemmas of the Early Childhood Professional", in Early Childhood Research Quarterly, 5:461-474, 1990.

Cooper, D. "Perceptions of Issues in Early Childhood Teacher Education", paper presented at the NZ Association for Research in Education Conference, University of Waikato, December 1993.

Cooper, D. and Royal-Tangaere, P. "A Critical Analysis of the Development of Early Childhood Education in Aotearoa", in E. Coxon et al., Politics of Teaching and Learning in Aotearoa, Palmerston North: Dunmore Press, 1994.

Dalli, C. and Cherrington, S. "Survey of Ethical Concerns of Early Childhood Educators: Preliminary Results", Paper presented to NZ Association for Research in Education Conference, Christchurch: December 1994.

Department of Education. Before Five: Early Childhood Care and Education in New Zealand, Wellington: Department of Education, 1988

Dresden, J. and Kimes Myers, B. "Early Childhood Professionals: Towards Self-Definition", in Young Children, January 1989.

Ebbeck, M. "Preparing EC Personnel to be Pro-active, Policy-making Professionals", in Early Child Development and Care, 58:87-95,1990. 
Feeney, S. Who Am I in the Lives of Children, Merrill, 1987.

Feeney, S. and Kipnis, K. Code of Ethical Conduct and Statement of Commitment, Washington DC: NAEYC, 1992.

Goffin, S. and Lombardi, J. Speaking Out: EC Advocacy, Washington DC: National Association for the Education of Young Children (NAEYC), 1991.

Goodnow, J. "Setting Priorities for research on group care for children", in Australian Journal of Early Childhood, 4:1, 1989.

Hayden, J. "Gender Equality versus motherhood ideology: Child care policy implications", in Early Child Development and Care, 1991:76:105113

Hindin, D. The Net, Christchurch: Independent Media Services, June 1994:15.

Holmes, T. An Investigation into the Scope and Viability of a Centre for Early Childhood Studies/Te Pumanawa Rangahau Kohungahunga within the Wellington College of Education and Victoria University of Wellington Faculty of Education: A Report to the NZ-US Educational Foundation, December 1994.

Hostetler, L. "Child Advocacy: Your professional responsibility?" in Young Children, 36:3, 1981.

Johnson, J. and McCracken, J. The Early Childhood Career Lattice: Perspectives on Professional Development, National Association for the Education of Young Children, NAEYC, 1994.

Kagen, S. "The New Advocacy in Early Childhood Education", Teachers College Record, 90:3, Spring 1989.

Kagen, S. "Policy Changes for the 21st Century", in Early Childhood Towards the 21st Century, Yew Chung Pub Co, 1990.

Kagen, S. "Leadership: Rethinking it - Making it happen", in Young Children, July 1994.

Kagen, S. and Riviera, A. "Collaboration in Early Care and Education: What can and should we expect?" in Young Children, November 1991.

Katz, L. "The Professional Early Childhood Teacher", in Young Children, July 1984.

Katz, L. "Trends and Issues in the Dissemination of Child Development and Early Education Knowledge", Opening address at the 1st Warwick International Early Years Conference, England: University of Warwick, March 1993.
Kell Easting, S. "Early Childhood Services: For Women or for Children?" in C. Briar, R. Munford and M. Nash (eds), Superwomen, Where are You? Social Policy and Women's Experience, Palmerston North: Dunmore Press, 1992.

Lambert, B. Changing Faces: The Early Childhood Profession in Australia Australian Early Childhood Association (AECA), 1992

Lombardi, J. "Training for Public Policy and Advocacy", in Young Children, May 1986

May, H. "A Post-Meade Reflection on Early Childhood Policy", in Te Timatanga, 9:2, 1991.

May, H. "After 'Before Five': The Politics of Early Childhood Education in the Nineties", in Te Timatanga, 10:2, 1992.

Meade, A. "Education to be More", Report of the Early Childhood Care and Education Working Group (The Meade Report), 1988.

Meade, A. "Women Gain a Foot in the Door", in Te Timatanga, 9:2, 1991.

Meade, A. and Wylie, C. "Competent Children. Influences of Early Childhood Experiences", (Milestone report), October 1994.

Ministry of Education. Te Whariki: Draft Guidelines for Developmentally Appropriate Programmes in Early Childhood Services, Ministry of Education, 1993.

Morgan, G et al. "Future Pursuits: Building Early Care and Education Careers", in Young Children, March 1994.

Nuttall, J. "Living with 'Before Five"', in Te Timatanga, vol 9, no 2, 1991

Phillips, D. (ed). Quality Childcare: What Does the Research Tell Us? National Association for the Education of Young Children (NAEYC), Washington DC, 1987.

Pickens, K. "Computer-Based Information Services for Education and the Social Sciences: A Review of Recent Developments", in Journal of Documentation, 46:2, June 1990.

Pickens, K. "A New Zealand Education Index or The Search for the Holy Grail: Episode 27", in NZ Libraries, 47:7, September 1993.

Radomski, M. "Professionalisation of Early Childhood Educators: How far have we progressed?", in Young Children, July 1986.

Rodd, J. "Keeping up with the latest: How about an Early Childhood Clearinghouse?", in Australian Journal of Early Childhood (AJEC), 15:2 1990.

Rodd, J. Leadership in Early Childhood, Teachers College Press, 1994 
Silin, J. "Authority as Knowledge: A Problem of Professionalization", in Young Children, March 1985.

Smith, A. "Early childhood on the Margins", in Australian Journal of Early Childhood, 15:4, 1990.

Smith, A., Hubbard, P., Ford, V and White, E. "Staff Working Conditions, Training and Job Satisfaction in Infant Childcare Centres: Relationships with Quality", Paper presented to NZ Association for Research in Education (NZARE) Conference, Christchurch: December 1994.

Spodek, B., Saracho, O. and Peters, D. Professionalism and the Early Childhood Practitioner, New York: Teachers' College Press, 1988.

Stonehouse, A. “Nice Ladies Who Love Children: The Status of the Early Childhood Profession in Society", Paper to the Australian Early Childhood Association (AECA) Conference, 1988.

Stonehouse, A. and Creaser, B. "A Code of Ethics for the Australian Early Childhood Profession: Background and Overview", in Australian Journal of Early Childhood (AJEC), 16:1, 1991.

US National Association for the Education of Young Children. "Position Statement: A Conceptual Framework for EC Professional Development", in Young Children, March 1994.

US National Institute for Early Childhood Professional Development (US NIECPD). "A Vision for Early Childhood Professional Development", in Young Children, November 1991.

Willer, B. and Bredekamp, S. "A 'New' Paradigm of EC Professional Development", in Young Children, May 1993.

\section{The author}

Tony Holmes is a lecturer in early childhood education at the Wellington College of Education. His major interests are in the sociology and history of education, the care and education of infants and toddlers, indigenous peoples' early childhood education, and in the professionalisation of the early childhood sector. 